\title{
GREPEN UIT DE GESCHIEDENIS DER DELFTSCHE BROUWNERING.
}

Een ongedateerde ,ordonnantie van der brouwerie ${ }^{3}$ ), blijkbaar stammend uit de jaren tusschen 1536 en $1555^{35}$ ), bepaalde dat, wanneer de accijns van de brouwerij niet was verhuurd, die zou worden bediend door twee van stadswege aangestelde excijsenaars. De door deze twee ambtenaren te innen accijns blijkt, toentertijd, een samenstel van door de brouwers verschuldigde belastingen te zijn geweest. Per brouwt van 41 stokstuks bedroeg de eigenlijke accijns van de brouwerij 13 st. en 1 blank, daarbij kwam dan voor 't gruit- en hopgeld $2 \frac{1}{2}$ st., en $1 \frac{1}{2}$ st. voor den turfaccijns, dus te zamen 17 st. 1 blank. Hiervoor zou nu in 't vervolg de excijsenaar per vat bier stokstuks 7 penn. hollandsch ontvangen, dat stond dus voor een brouwte van 41 stokstuks zoo goed als gelijk met het bovengenoemde bedrag ${ }^{\text {10 }}$ ). Daarbij kwam dan natuurlijk nog 7 penn. voor elk overgebrouwen vat stokstuks. Beide excijsenaars moesten zich tot het ontvangen van den accijns dagelijks ,ter geordineerder plaatse" bevinden, n.l. van Mei tot Allerheiligen' 's morgens van acht tot elf en na den middag van twee tot vijf uur, van Allerheiligen tot Mei van acht tot elf en 's middags van één tot vier. Ze moesten altijd mèt hun tweëen samen zijn om het register bij te houden en 't geld te innen; wie op grond van ziekte of om een andere wettige reden met toestemming van burgemeesteren afwezig was, moest een ander in zijn plaats stellen, die dan evenals de vaste excijsenaars door burgemeesteren zou worden beëedigd. Dit voorschrift lag voor de hand: immers men moest altijd in staat zijn om de door de

1) Keurboek II, fol. 252.

$\left.{ }^{16}\right)$ De ordonnantie spreekt van het gruit- en hopgeld, toekomend aan den graaf van Holland en den heer van Wassenaar samen; in $1555 \mathrm{nu}$ is Delft door Karel $V$ met de grafelijke helft van het gruit- en hopgeld beleend.

${ }^{36)} 1$ st. $=16$ penn.

Econ. 1920. 
excijsenaars gehouden registers van de tonnen bier of zooals 't heette van de gijlen met elkander te controleeren.

Gijl of gijlbier werd het bier genoend, wanneer het in de gijlkuip voor de eerste maal tot gisting was gebracht. Het gijl werd "op de stellinge gevaat", d.w.z. uit de gijlkuip overgebracht in vaten, die men in een kelder of een andere lokaliteit, waar het 's zomers koel en 's winters warm was, plaatste op stellingen, onder welke vloten of onderbakken geschoven stonden, waarin de gedurende de tweede periode van gisting gevormde gist kon afloopen: Omstreeks het midden der zestiende eeuw nu blijkt in Delft het instituut der gijlinslagers te zijn ingesteld; voor ' $t$ eerst vind ik ze genoemd in een keur van 28 Januari $\left.1544^{\prime \prime}\right)$. Een uitvoerige „ordonnantie van de ghijlinslagers” dateèrt blijkbaar van tusschen 1553 en $1570{ }^{15}$ ). Om te verhoeden alle fraude en bedrog, zoo heet het, 't welk zou kunnen worden gepleegd tèn opzichte van excijnsen, imposten, hopgeld e.a. recht, zou het vaten van bier uit het gijl in tonnen, halve tonnen, kinnetjes en achtendeelen „op 'de stellinge” alleen mogen gebeuren door een gezworen inslager of nood-inslager, wien 't werk bij dobbelen ten deel gevallen was - op verbeurte van 10 pond voor den brouwer zoowel als voor den onbevoegde die voor hem het gijl insloeg. Terstond nadat het vaten van 't bier had plaats gehad, moest de gijlinslager zooals dat heette den excijsenaar 't gijl gaan aanbrengen, d.w:z. voorzien van een ,cedulle" van den brouwer, waarop het aantal ingeslagen tonnen, halve tonnen enz. stond aangegeven, den verschuldigden accijns betalen. Bij' wijze van controlemaatregel had de gijlinslager het aantal tonnen enz. vooraf 'mondeling op te geven, en ingeval deze opgave niet met de schriftelijke overeenstemde, mocht de excijsenaar de aangifte niet in ontvangst nemen. Merkte een gijlinslager iets van smokkelen-doordat er bieren uit het gijl dat hij werkte door een ander tevoren waren uitgeslagen, of doordat men gijl achterhield om het clandestien te laten uitslaan - dan moest hij dat ook, op boete van 10 pond en correctie van schepenen, terstond aan den excijsenaar te kennen geven.

$\left.{ }^{27}\right)$ Keurboek II, fol: 123

$\left.{ }^{18}\right)$ Keurboek II, fol. 256. Artikelen betreffende hooftmans, welke in 1553 aan een andere ordonnantie, te vinden Keurboek II, fol. 123 vs., zijn toegevoegd, vinden we in onze ordonnantie vermeld als geschrapt, terwijl: de oudste veranderingen blijken te zijn aangebracht in 1570 . 
De verplichtingen van gijlinslagers en brouwers beide werden bij de ordonnantie in alle details nauwkeurig geregeld. De inslagers moesten zich in 't huisje bevinden van 's ochtends dat de werkklok der Nieuwe Kerk luidde totdat 's avonds dezelfde klok' weer luidde voor 't naar huis gaan; op. Zon- en feestdagen moesten zij van elf tot twaalf, in den zomer 's namiddags van zes tot zeven en 's winters van Allerheiligen tot Lichtmis van vier tot vijf, van Lichtmis tot. Paschen van vijf tot zes uur aanwezig zijn. Een inslager die niet op 't afgesproken uur present was, en ook niet verscheen als de brouwer hem nog eens had laten waarschuwen, verbeurde 20 st.; daartegenover stond, dat de inslager op het uur 't welk de brouwer hem genoemd had het gijl ook gereed moest vinden, anders was de brouwer hem 1 st. schuldig. Ook kon de brouwer geen bepaald uur vaststellen, maar den inslager laten halen wanneer het tijd was, wel te verstaan dat, wanneer er intusschen weer om werk gedobbeld werd, de inslager mee-dobbelen mocht, mits hij dan den brouwer waarschuwde. Een brouwer, die door een inslager was gedupeerd, stond het, binnen de uren, vrij om opnieuw te doen dobbelen; buiten de uren kon hij aan den hoofdman on een anderen inslager verzoeken. Eveneens moést hij zich tot den hoofdman wenden; wanneer hij verzuimd had om bijtijds, zooals dat heette, om zijn werk te laten dobbelen, zoodat zijn gijl ,toequam', d.w.z. gereed was voor 't inslaan, zonder dat er een inslager bij de hand was; de brouwer verbeurde dan ,voor zijn negligentie" 10 st. Als arbeidsloon ontvingen de inslagers 3 st. per last ${ }^{20}$ ), $\frac{1}{2}$ last en daarboven gold voor een vol last; wat beneden $\frac{1}{2}$ last was, werd niet gerekend.

Den inslagers werd nadrukkelijk voorgeschreven om hun werk "getrouwelijk" te doen en in de brouwerijen , heuschlijken te waridelen", zonder er te mogen tappen of drinken anders dan hun doör meester of vrouw werd toegestaan, op boete van 3 pond en correctie van schepenen. Wie ,hoog bij.drank" of dronken uit de brouwerij of in 't inslagershuisje kwam, werd voor een mand geschorst. 't Was ook verboden om bier in het huisje te brengen' of door een ander te laten halen; evenzoo, op straffe van voor veertien dagen te worden geschorst, om in 't inslagershuisje of in de buurt.daarvan op straat te spelen of te dobbelen om geld. Dat de inslagers èn. onder hun werk niet altijd de verleiding, weerstaan;

$\left.{ }^{10}\right) 12$ tonnen. 
konden èn in hun ledigheid dikwijls kwamen tot ongewenscht en verkeerd tijdverdrijf, was dus aan de Delftsche overheid al bekend.

Het instituut der gijlinslagers heeft in Delft bestaan tot 1676; uit het Resolutieboek der Gemeene Brouwers ${ }^{20}$ ) blijkt, dat de confrerie hun na dat jaar een wekelijksche toelage uitkeerde om hun, nu hun ambt opgeheven was, financieel tegemoet te komen. Het jaar $1676 \mathrm{nu}$ is dat van de afschaffing voorgoed van den impost op de gijlen of den ton-biers-impost, die vanwege de provincie werd geheven, en bestond in een heffing van 2 st., sinds 16714 st., per ton bier „op de stellinge gevaat”. Deze impost is één van de wreinige middelen geweest die, althans gedurende eenigen tijd, ingevolge artikel $\mathrm{V}$ der Unie van Utrecht in enkele provinciën -- Holland, Zeeland, Utrecht en Gelderland - op eenparigen of zoo goed als eenparigen voet geheven zijn ${ }^{21}$ ). De heffing diende te geschieden op den voet der ordonnantie van de Staten Generaal van 1 Maart $1584^{22}$ ), welke o.m. bepaalde, dat het vaten van het bier slechts mocht worden gedaan door gezworen inslagers, en nauwkeurig hun werkzaamheden en verplichtingen vaststelde.

Uit het voorafgaande bijikt nu, dat de Staten Generaal bij hun ordonnantie een reeds bestaande plaatselijke instelling voor alle brouwsteden der Unie algemeen hebben zoeken te maken. Was Delft misschien de eenige stad, die het hooge college in dezen heeft geïnspireerd ? Waarschijnlijk lijkt mij dat niet, maar dat er vóór $1584 \mathrm{nog}$ in niet veel steden gijlinslagers werden gebruikt, blijkt in elk geval uit een in de Staten van Holland van $15 \mathrm{Fe}-$ bruari 1586 door Delft te berde gebrachte klacht, dat zijn hoofdnering zich onmogelijk onder den druk der ton-biers-belasting zal kunnen staande houden, wanneer niet in alle andere brouwsteden evenzoo ingevolge de ordonnantie gijlinslagers worden aangesteld en dus de vereischte controle plaats vindt. M.n. Haarlem, Leiden en Amsterdam bleven aanvankelijk in gebreke om inslagers te benoemen, hebben ze dus ook vóor 1584 nooit te werk gesteld.

20) Gem.-arch. v. Delft.

${ }^{21}$ ) Zie uitvoerig over den impost op de gijlbieren mijn artikel in de Bijdragen voor vad. geschiedenis en oudheidkunde, 5e Reeks III, blz. 360 vig.

$\left.{ }^{2}\right)$ Groot Plackaet-Boeck II, 2164. 
Wanneer we nu in 1676 met den provincialen impost op de gijlbieren in Delft de gijlinslagers zien verdwijnen, dan dringt zich de vraag aan ons op, hoe het "geloopen is met den door de brouwers verschuldigden stedelijken accijns perr ton bier, welker betaling immers door middel van het instituut der gezworen inslagers moest worden gecontroleerd. In de keuren uit de zeventiende ceuw vinden we van dezen stedelijken accijns g̀een melding meer gemaakt. Dat hij toen dus niet meer geïnd werd, mogen we uit éen der beide feiten - 't verdwijnen, of het niet meer vermelden der gijlinslagers - nog niet afleiden; te zamen echter wijzen ze wel in die richting. En het komt mij voor dat, wanneer wij dit aannemen, een verdere conclusie voor de hand ligt: men zal het niet zoo moeten opvatten, dat ingevolge artikel $V$ der Unie ten behoeve van de Generaliteit o.m. een nieuwe provinciale impost op het bier werd ingesteld, maar dat de opbrengst van een in verschillende plaatsen geheven stedelijken accijns voortaan ten bate zou komen van het gemeene land - welke nu in een impost veranderde accijns dan uit den aard der zaak moest worden opgebracht door alle brouwsteden, tot cen gelijk bedrag, 't welk voor Delft althans ongetwijfeld hooger is geweest dan hetgeen de stad per ton bier placht te innen ${ }^{5}$ ). Dat de Generaliteit met den stedelijken accijns ook de hier en daar bestaande controle-instelling, d.w.z. de gijlinslagers, overnam, komt ons nu in dit licht bezien logisch en vanzelfsprekend voor.

Met het aldus voor de provincie, in hougste instantie voor de Unie generaliseeren van een plaatselijk geheven accijns, ging men overigens voort in de lijn van wat men reeds vroeger, in 1573, had in praktijk gebracht, toen, aldus een Delftsche keur uit dat jaar ${ }^{24}$ ), door ridderschap, edelen en gedeputeerden van de steden van Holland staatsgewijs vergaderd eendrachtelijk besloten was, dat zoowel de groote als de kleine steden van 't gewest voor een tijd zouden in 't gemeen brengen al hun inkomsten aan accijnzen en anderszins, teneinde te voorzien in de groote tot bescherming der landen benoodigde kosten, welke uit de imposten en buitengewone onkosten en bijdragen niet konden worden gevonden.

Met de grafelijke helft van het hopgeld - hetwelk, naar men gezien heeft, in het bedrag van den door de stad geheven accijns

${ }^{23}$ ) Zie boven, blz. 415. Het is natuurlijk niet gezegd, dat in 1584 het bedrag van den stedelijken accijns nog onveranderd was.

${ }^{24}$ ) Keurboek III, fol: 155 . 
was inbegrepen - was Delft o.m. beleend in $1555^{25}$ ); de andere helft, welke den heeren van Wassenaar competeerde, kocht de stad in 1660 van' den prins var Ligne, op wien de rechten en bezittingen van het geslacht Wassenaar bij erfenis waren overgegaan ${ }^{25}$ ).

Groote of consumptie-impost heette, ter onderscheiding van den door de brouwers op te brengen impost op de gijlbieren, de belasting op het bier, welke de provincie van den consument hief. Zoo is eveneens behalve den boven besproken accijns per ton bier, dien we niet met een bepaalden naam vinden aangeduid, maar die ook gijl-accijns zou kunnen worden genoemd, in Delft de gewone consumptie-accijns geheven, te betalen door alle bierverbruikers met uitzondering van enkele categorieën. Een ordonnantie uit het begin der zestiende eeuw ${ }^{37}$ ), aangevuld in $1537{ }^{28}$ ), noemt als zoodanig schout, dijkgraaf, heemraden, den pensionaris en de tresoriers, de brouwers zelf en de geestelijke personen. Laatstgenoemden genoten echter niet meer dan een beperkten vrijdom, en dat voorzichtiglijk tot wederopzeggens toe: van drie halve vaten per termijn voorzoover $z$ ij huis, vuur en licht hielden, terwijl degenen die bij anderen in de kost lagen elken termijn één halfvat accijnsvrij hadden. 't Bagijnhof kon volstaan met iederen termijn drie guillelmusschilden te betalen. Accijnsvrij, eveneens tot wederopzeggens toe, zouden ook de scheepmakers zijn voor het bier 't welk hun geschonken werd op de schepen die zij vervaardigden of herstelden, niet voor wat zij binnen hun huizen of erven met hun huisgezin of op hun timmerwerven dronken. Voor wereldlijke personen, die in conventen of bij geestelijken in de kest lagen, was men den accijns van èn halfvat verschuldigd; evenzoo een brouwers voor vrienden, magen of andere kostgangers van boven de twaalf jaar. Brouwers en geestelijke personen mochten niet meer dan éen mingelen bier accijnsvrij buiten hun huis of hof weggeven. De stad stond niet toe, dat haar burgers haar te kort deden door buiten haar gebied en vrijheid hun dorst te gaan lesschen; wie zulks deed, verbeurde 3 pond, wanneer althans schepenen hadden uitgemaakt dat hij zoover ,principalicken" was

${ }^{25)}$ Van Bleyswijck, blz. 94 .

${ }^{26}$ ) Van Bleyswijck, blz. 100.

$\left.{ }^{27}\right)$ Keuren en ordonnantiëņ, blz. 216.

${ }^{28}$ ) Keurboek 11, fol. 26. 
gegaan om te drinken - een naar 't mij voorkomt niet gemakkelijke beslissing.

De-stad hief, natuurlijk, ook accijns van de niet-Delftsche of vreemde bieren, die werden ingevoerd en binnen Delft geconsumeerd; welke accijns door een aparten ,excijsenaar van der vreemde bierexcijse" werd geïnd. Wie vreemd bier van buiten in de stad bracht, was verplicht om binnen een ${ }_{1}$ uur aan dien excijsenaar. te kennen te geven, wat voor soort bier en hoeveel crvan hij had aangevoerd, op boete van drie pond hollandsch, terwijl hij vóor die aangifte zijn last niet breken mocht. Ook mocht niemand vreemd bier inslaan, op het land uitleveren, in zijn huis ontvangen of zooals dat heette ,werken" zonder er tevoren den excijsenaar van te hebben kennis gegeven.

Het ,werken" van het bier, d.w.z. 't bezorgen ervan uit brouwerijen en schepen daar waar het wezen moest, mocht, ook al uithoofde van de controle op de accijnsbetaling, alleen gebeuren door de gezworen stadsbierkruiers ${ }^{\text {2n }}$ ). De kruier ontving het ,loot" of loodje, 't welk door dengene die bier wenschte op te' doen gehaald was bij den excijsenaar. Blijkbaar waren er voor vaten, halve vaten en kinnetjes verschillende ,Ioen", - en ook bepaalde kenbare voor "vrije" personen. Alleen wanneer de brouwer wiens naam de consument aan den excijsenar had moeten opgeven - zulk een lood van den kruier ontvangen had, mocht hij het bicr uitleveren. De excijsenaar kwam later bij den brouwer de loodjes ophalen en aldus den accijns innen, welken de brouwers natuurlijk op hun beurt aan hun klanten in rekening brachten. In aanmerking genomen nu dat de bierkruiers onder eede stonden, zou men verwachten dat op deze wijze de controle op de accijnsinnning behoorlijk verzekerd was - maar allerminst! Burgers. brouwers en kruiers - geen van 'de drie categorieën achtte zich te goed voor fraude. Uit een keur van $1536{ }^{30}$ ) blijkt, dat burgers vaak bier inlegden zonder een loodje te hebben gehaald, dat brouwers dienovereenkomstig 't bier uitleverden zonder lood te hebben ontvangen, terwijl bij de heele transactie de bierkruiers de behulpzame hand ook zonder al te nauw te kijken - hetgeen alles bij de bedoelde keur op boete verboden werd ${ }^{31}$ ). Een

${ }^{\text {s) }}$ Zie over de bierkruiers ook mijn artikel: Uit de nadagen der Delftsche brouwneering, Economist 1916.

эi) Keurboek II; fol. 5 vs.

${ }^{31}$ ) Het bedrag van de boete is niet goed leesbaar. 
andere wijze van fraudeeren in 't pizonder door de brouwers toegepast schijnt te zijn geweest om minder loodjes af te leveren dan zij inderdaad ontvangen hadden, tenminste onder de in 1537 aan de eerstgenoende ordonnantie toegevoegde artikelen "s) vinden wij het nog al radicale voorschrift, dat de excijsenaar geen "loen" uitgeven mag "op" brouwers die in gebreke zijn gebleven om al hun loodjes in te leveren. Ging dat gepaard met oplichterij van de klanten, doordat hun dan toch de accijns in rekening werd gebracht? dan zou dit feit ons al een zeer ongunstigen kijk op de brouwers geven. Maar vermoedelijk is er in de meeste gevallen niets dan slordigheid in het spel geweest : dat kunnen wij opmaken uit de bepaling, dat de brouwers de ,loen" moeten wegsluiten en nergens „,buiten sloten leggen of hangen”, opdat zij ze elken Maandag vóor acht uur - Dinsdag, wanneer er op Maandag juist een heiligendag viel - gereed hebben om ze aan den excijsenaar over te leveren.

De bovenbeschreven wijze van den accijns te innen door middel van controle met loodjes is blijkbaar niet lang in gebruik gebleven. In een ordonnantie van $1574_{a^{33}}$ ) op de inning zooals die ten behoeve van het Gemeene Land plaats hebben zou'") wordt voorgeschreven dat, wie bier (of wijn) wilde inslaan, eerst, op verbeurte van 10 pond, een biljet van den collecteur of zijn gecommitteerde teekenen moest, bevattend den prijs van het bier of den wijn; door den kooper op die opgave een eed te doen afleggen trachttte men fraude te voorkomen. Overigens analoge bepalingen als in de vroegere ordonnantie: de brouwers mochten geen bier uitleveren dan naar inhoud der biljetten, welke alle acht dagen door den collecteur bij hen zouden worden opgehaald.

In later tijd vinden we weer een andere methode: dan betaalt de burger zelf zijn accijns, waarbij hem gelijktijdig het biljet bevattend kwantiteit en kwaliteit van het door hem in te leggen bier wordt ter hand gesteld ${ }^{\text {s5 }}$ ). Een wel zoo praktische regeling, maar, zooals herhaaldelijk blijkt, ter wering van fraude even weinig afdoende: men bleef bier inleggen zonder dat er vooraf éen biljet voor was gehaald, belaste bieren onder den schijn van

s2) Zie boven, blz. 420 .

${ }^{33}$ ) Keurboek III, fol. 207 vs.

3) Zie boven, blz. 418 .

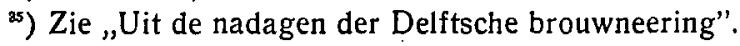


dunnebier smokkelen; tappers wisten bier te bekomen waarvoor slechts burger-accijns betaald was.

Terwijl de ordonnantie uit het begin der zestiende eeuw merkwaardigerwijze het bedrag van den accijns niet noemt, geeft die van 1574 ons daaromtrent meer uitsluitsel. Tusschen bieren binnen de stad, in Holland of buiten de provincie gebrouwen wordt geen onderscheid gemaakt. Tappers moesten van elk vat bier van 2 gld. of minder 15 st., accijnsplichtige burgers en huislieden 10 st. per ton betalen; op alle zwaardere bieren kwam bovendien nog zooveel als de ton boven de 2 gld. had gekost. Halve vaten, kinnetjes en achtendeelen naar advenant. Het paste in 't geheele systeem van controle, dat er geen bier uit de brouwerijen geleverd mocht worden c'an in van stadswege geijkt vaatwerk.

Er werd zoo dikwijls zwaar voor licht bier versmokkeld, dat men 't geraden achtte om bij ordonnantie van 6 Januari $1593^{\text {as }}$ ) den burgeraccijns voor alle ingebrouwen, $d$. i. binnen de provincie gebrouwen, bieren kort en goed op 8 st. de ton te stellen ${ }^{3 i}$ ). Een ordonnantie, welke misschien van 1640 dagteekent ${ }^{38}$ ), regelde $n$ og eens uitvoeriger alles wat op den accijns zoowel op binnenlandsch als op van buiten de verbonden gewesten en over zee komend bier betrekking had. De burgeraccijns zoowel voor zware als voor lichte bieren bleef 8 st. per ton. De klein-bier-tappers dat waren degenen die goedkoope bieren, echter geen dunnebier of scheys mochten slijten ${ }^{\text {ag }}$ - waren voor een ton bier van 3 gld. of minder 10 st. accijns verschuldigd, voor zwaarder bieren 24 st. per ton, evenals alle herbergiers en zware-bier-tappers. Voor 't vreemde bier moest men per ton 42 st., voor 't vat jopen- of Danziger bier 4 gld. betalen.

$\mathrm{Na}$ 't afschaffen van de verpachtingen vond het innen van den stadsbieraccijns in Delft door een gaarder plaats; van 5 De-

$\left.{ }^{36}\right)$ Keurboek IV, fol. 210.

$\left.{ }^{3 r}\right)$ Denkelijk zal vóór dat jaar de bieraccijns in Delft wel reeds tot een ander bedrag zijn geheven dan bij de ordonnantie van 1574 was vastgesteld.

$\left.{ }^{35}\right)$-Aanwezig in het gem.-archief van Delft, maar niet in de keurboeken opgenomen.

${ }^{30}$ ) Dunnebier was het product van een herhaalde bewerking op de speciën, welke al tot het brouwell van zwaar bier hadden dienst gedaan. De lichte biersoorten verkreeg men door in de gijlkuip het zware bier met dunnebier in de gewenschte verhoudingen aan te lengen. 
cenber 1752 dagteekent de eerste ordonnantie op deze nieuwe wijze van invordering ${ }^{\star n}$ ). Ook ten opzichte van den tappersaccijns maakt deze keur geen onderscheid tusschen zwaar en licht bier meer. De groote tappers betaalden nu per halfvat 9 , de kleine 5 st.; voor de burgers was de accijns 4 st. per halfvat, dus als vanouds. Voor groote tappers, werd nu uitgemaakt, zouden worden gerekend degenen, die wijngelagen zetten en tevens bier of mol voor geld in hun huizen lieten drinken, terwijl ook de z.g.n. koffieschenkers, voorzoover het de mol of andere bieren, welke zij tegen betaling schonken, betrof, als groote tappers werden beschouwd. Allen die bier schonken of met de kan uitsleten, doch zonder bovendien wijn te tappen, vielen onder de categorie der kleine tappers.

Een generale ordonnantie ten slotte op te heffing der accijnsen van de stad bij wege van collecte ") van denzelfden datum 5 December 1752 noemt de autoriteiten en corporaties, die van betaling der accijnsen waren vrijgesteld: de regeerende heeren schout, burgemeesteren, schepenen, weesmeesters, havenneesters, en thesaurier, pensionarissen en secretarissen mitsgader's den secretaris van de Weeskamer, dijkgraaf en hoogheemraden vall Delfland met secretarissen en penningmeester, benevens predikanten der Nederduitsche en Waalsche Gereformeerde Kerken allen met hun weduwen, voorzoover zij overleden waren of voortaan in functie mochten overlijden. Tevens de collegiën, godshuizen en notabele personen, welke evenzoo door de Staten van Holland bij plakkaat van 22 . Juli $1749^{12}$ ) van de betaling van 's lands rechten waren vrijgesteld; voorts de stad voor de middelen van contumptie, die op officiëele maaltijden werden gebruikt, den wijn, dien zij inlegde, en de turf, die zij opdeed; dijkgraaf en hoogheemraden van Delfland voor 't geen..zij tijdens hun bijeenkomsten in hun logement gebruikten; de schutterij voor wijn en bier, die bestemd waren om op haar vergaderingen te worden gedronken; de West-Indische Compagnie voor al de speciën van consumptie, welke zij in Delft insloeg, de Oost-Indische echter slechts wat betrof het voor haar bemanningen ingeslagen gerookte spek; en ten slotte allen, die zouden kunnen aantoonen uithóofde

40) Keurboek X, fol. 120 vs.

1) Keurboek $X$, fol. 118.

32) G. P. B. III, 1005. 
van hun trafiquen bij speciaal octrooi, privilege of contract eenigen vrijdom te hebben verkregen.

Een tweeledig doel hadden de hopordonnanties der stad: toezicht op de kwaliteit donr keuring, en op de accijnsbetaling door 't meten van de verhandelde hoeveelheden. De oudst-overgeleverde keur: ,van hoppe en 't meeten van die" dagteekent blijkbaar uit het begin der zestiende eeuw ${ }^{i 3}$ ), een latere ordonnantie van $15.54^{41}$ ). Geen hop mocht worden opgedaan en daartoe overgestort, in 't kort verhandeld, welke niet eerst door gezworen hop- of keurmeesters gekeurd was. Typischmiddeleeuwsch-particularistisch bepaalt de ordonnantie van 1554 , dat afgekeurde hop weer buiten de stad moet worden gevoerd. Knoeien met de hop gebeurde m.n. door 't vermengen van oud met nieuw gewas; voor nieuwe hop werd, blijkens de keur van 1554, gerekend al 't nieuwe gewas tot Kerstmis toe. Alleen na Kerstmis mocht men alle hop tegelijk in éen huis en door elkander gemengd opdoen, natuurlijk totdat weer het nieuwe gewas werd geoogst. Het meten geheurde, nadat de hop gekeurd was, door den gezworen meter: „en dat," aldus de ordonnantie, ,met die schup ophopende dat achtendeel sooveel en hoog als men dat'sal mogen opkoopen". De hopverkooper had van elk hoed $1 \frac{1}{2}$ groot te betalen, n.l. voor 't recht van de stad 1 groot en $\frac{1}{2}$ groot voor arbeidsloon aan den meter, welken laatste uitdrukkelijk verboden werd om nog iets daarboven aan te nemen in den vorm van drinkgeld, steekpenning of hoe men 't anders noemen zou. Echter ontving de meter van elke verkochte en door hem gemeten hoeveelheid hop van boven de drie tot aan twaalf hoed zelf, zooals de keur het noemt, een , uitsette" van een achtendeel, dat evenzon mocht worden ,"met de schup opgehoopt" als de geheele partij, maar niet op eenigerlei wijze ingedrukt; van iedere twaalf hoed boven 't eerste dozijn kwam den meter weer een ,uitsette" toe. De hopmeter had er zich vooraf goed van te verzekeren, dat de hop die hij meten zou reeds verkocht was, en binnen vier-en-twintig uur den excijsenaar van $z$ ijn verrichte werk kennis te geven. We zullen uit deze bepaling moeten besluiten, dat de accijns ten laste van den kooper kwam. De oudere keur maakte i.z. accijnsbetaling nog verschil tusschen pondhop en hand- of hoedhop van de

43) Soutendam, keuren en ordonnantiën, blz. 158.

"4) Keurboek II, fol. 151 vs. 
eerste, die bij 't pond werd verkocht en geworpen of gestort, kwam de accijns ten laste van den verkooper; de accijns van handof hoedhop, zoo genoend ondat ze bij 't hoed verkocht werd en, toentertijd blijkbaar, met de hand ingedrukt, moest door den kooper worden voldaan.

De heele hopaccijns is in 1743 door burgemeesteren te niet gedaan, wel te verstaan tegen jaarlijksche betaling van een „,convenabele" som door de brouwers, die reeds geduren de jaren tevoren voor hun hop, welke in Rotterdan werd geleverd en gewogen, in hun woonplaats geen accijns plachten te betalen. Wel werd in Delft de accijns nog verpacht, maar voor niet meer dan 1 gld.; en om een eind te maken aan ,vexatiën" van den pachter, die toch soms nog tráchtte accijns van hen los te krijgen, heeft de confrerie der brouwers in 1743 den accijns afgekocht.

Gaan wij, ten slotte, ook de geschiedenis na van de organisatie der Delftsche brouwers: van hun gilde dus. Terwijl de brouwers, zooals wij gezien hebben, niet schroomden om zich te laten gelden wanneer zij hun bedrijf in economisch opzicht zagen aangerand. blijkt ons nergens iets van een politieke rol door hen gespeeld, en keurèn uit de zestiende eeuw laten feitelijk alleen op hun godsdienstig optreden eenig meer licht vallen. De jaarlijksche bijdrag 2 van iederen broeder voor de godsdienstige functie van 't gild bedroeg, naar een „ordonnantie van 't gilde van de brouwers" "), 8 groot; voor doodschuld gaf men 2 pond hollandsch, waarvoor den overledene dan dertig zielmissen toekwanien. Overigens deed het gilde vijf missen per week lezen, terwijl bovendien de hooftmans op kosten van het gild moesten ,uitbrengen die helle inder spele van Jesse", blijkbaar een mirakelspel, dat werd opgevoerd op den eersten Zondag na Sint-Odulfus, wanneer het beeld van Onze Lieve Vrouwe van Jessen in plechtigen ommegang door de stad gedragen werd.

In het laatst der zestiende eeuw schijnt, zeker wel onder den invloed der Hervorming, het "onderhoud van mis en godsdienst". - aldus een keur van 27 September $1571^{\circ 6}$ ) - door 't brouwersgilde in verval te zijn geraakt. De keur bepaalde daarom, dat niemand brouwen mocht tenzij hij 20 st. gaf voor inkomst en voorts alle jaren 10 st., voor doodschuld of bij 't scheiden uit de nering

${ }^{45}$ ) Soutendam, Keuren ell ordonnantiën, biz. 173.

${ }^{16}$ ) Keurboek III, fol. 90 vs. 
2 car. gld., alles tot onderhoud van den godsdienst, die gedaan moest worden in de Nieuwe Kerk op St. Sebastiaans-altaar: Een jaar tevoren was bepaald "), dat dè brouwers"tweemaal 's jaars,, n.l, op Heilige Sacraments- en op Heilige-Kruis-dag, elk een toorts voor 't heilige sacrament moesten dragen of doen dragen,' op boete van 12 st. Burgemeesteren zouden de toortsen doen makèn en aan brouwers en brouwsters thuiszenden, natuurlijk op hün kosten.

Betreffende de opname in het gild, directie enz. vinden wij in de achtereenvolgende ordonnanties zeer uiteenloopende bepalingen - een bewijs dat in de praktijk het gebruik zich voortdurend wijzigde. De oudste keur, die „raackende de brouwers” zegt, dat geen broltwersknaap te ketel staan mocht die geen poorter was voor een brouwer achtte mien dien eisch, naar 't schijnt, genoeg bekend en vanzelfsprekend, althans de keur formuleert haar niet. Maar wel gebeurt dit in latere ordonnanties, en dat op rigoureuzc wijze in de keur „,van der brouwerie”. Een niet ingeboren poorter moest, om in stad en vrijheid van Delft de brouwnering te mogen uitoefenen, niet alleen eerst poorter worden, maar ook ecn borgtocht stellen van 200 Rijnsche guldens, welk bedrag hij verbeurde wanneer hij binnen de tien jaar zijn poorterschap verzaakte, en ook als hij ging brouwen of een brouwerij oprichtte buiten de stad. De bepaling omtrent den borgtocht gold ook voor ingreboren poorters.

De hierboven genoemde ,ordonnantie van 't gilde van den ' ' wers" zegt weer niets van een borgtocht, bepaalt echter voor ecn niet-ingeboren poorter de som, die hij aan de stad geven moest aleer hij de brouwnering mocht uitoefenen, op 6 nobelen van 8 schellingen; op de helft, wanneer cen aspirant-brouwer met een geboren poorteres was gehuwd. Een geboren poorter hehoefde voor de ,intree" maar $\frac{1}{2}$ nobel te betalen.

Wij zullen wel niet mistasten, wanneer we deze voorschriften en vereischten in verband brengen met de minder gunstige omstandigheden in den tijd van 't uitvaardigen der beide bovenbedoelde keuren - de eerste helft der zestiende eeuw - en de monopolistische tendenzen, die zich toen onder de brouwers in 't algemeen gelden deden; men was in het opnemen van nieuwe gildebroeders niet meer zoo coulant als het naar 't schijnt vroeger het geval was geweest.

") Keurboek III; fol. 64. 
Blijkens een ongedateerde niet in de keurboeken opgenomen „keure en ordonnantie van de brouwerije, hooftneringe der stad Delft", die we denkelijk ongeveer in 't midden van de zeventiende ceuw moeten stellen, werd toentertijd alweer een hooger gilderecht geheven: n.l. van een buitenman of vreemdeling, die zijn poortrecht had gewonnen, 36 gld.; van een ingeboren burger 24 , van een brouwerszoon of-dochter echter 12 gld.; een vreemdeling, die met een burger- of brouwersdochter was getrouwd, had i.z. het brouwen het recht zijner huisvrouw. Naast het verlof aan directeurs en gemeene gildebroeders om voor elk jaar, teneinde ,te vervallen de ordinaris en extraordinaris lasten van het gilde" een omslag tê doen per brouwte, doet niet heel duidelijk aan de bepaling dat de gildebroeders jaarlijks 3 gld. moester contribueeren. Zou laatstgenoemd voorschrift nog slechts een overblijfsel zijn uit oudere keuren, terwijl in de praktijk de onkosten reeds geregeld door een omslag per brouwte werden gevonden ? In aanmerking genomen dat men noch in het Resolutieboek, 't welk loopt van 7 Maart 1676 tot 11 Augustus 1773, noch in het ,Reken Bouck van de gemeene brouwers binnen Delff" (1662-1772) iets over de jaarlijksche contributie vindt vermeld, terwijl wel geregeld het aantal gedane brouwten en hef bedrag van den omslag per brouwt wordt meegedeeld, lijkt mij deze verklaring wel het waarschijnlijkst.

$\mathrm{Nu}$ over het bestuur van ' $\mathrm{t}$ gild in den loop der tijden. In de keur "raackende de brouwers" vinden wij, dat een ,homan" minstens drie jaar lang poorter moet zijn geweest, en bovendien in 't -schotboek staan voor 100 pond of meer. Er waren vijf homans: het gemeene gerecht zou er elk jaar op Goeden Vrijdag drie kiezen, welke met de vier burgeneesters uit de schepenen de twee aridere hadden aan te wijzen.

De. volgende ordonnantie, die ,van der brouwerie", kent gezworenen van de brouwerij. Het komt mij voor, dat wij dit niet als een andere benaniing van ,hoofdlieden" hebben op te vatten, maar dat de gèzworenen in het brouwersgild vertrouwensmannen of functionarissen waren naast de hooftnaris, met een meer speciale opdracht en werkikring: Immers de ordonnatie schrijft voor, dat wie onvoorziens één of meer vaten boven den geoorloofden 'tax nocht brouwen; 'dit op staande voet gezworenen ,en den anderen gedeputeerden" moet te kennen geven; en verder wordt den gezworenen uitdrukkelijk op straffe van boete opgelegd on voor het gerecht te komen teneinde hun eed af te leggen, wanneer 
hun bij aflezing van de klok daartoe een bepaalde dag ",gezet en bevolen" worden zal. Hebben gezworenen wellicht controle op het overbrouwen moeten uitoefenen? Mocht dat zoo zijn, dan heeft ook deze maatregel, zooals uit het yoorafgaande gebleken is, niet aan het doel beantwoord.

Volgende ordonnanties kennen geen gezworenen meer: als bestuurders van het gild worden alleen hoofdlieden genoemd; later krijgen zij den naam van directeuren. De bovenbedoelde ,keure en ordonnantie van de brouwerije" regelt nog eens de geheele materie van gilde-intree, bestuur, enz. : alzoo, heet het in den aanhef, de keuren en ordonnantiën rakende het gild van de brouwneringe bevonden worden tot nog zoodanig niet te zijn geobserveerd als behoort. Er waren nu, zooals blijkt, vier directeuren : „,volgens voorgaande gebruiken" zouden jaarlijks op den derden Zaterdag in Januari de gemeene gildebroeders uit hun midden bij meerderheid van stemmen twee bekwame personen kiezen, ter vervanging van de oudste bij die gelegenheid aftredende directeurs, welke gedurende twee jaar niet herbenoembaar waren ; aan de beide nieuwgekozenen viel de administratie der penningen te beurt, waarvan zij jaarlijks behoorlijk rekening, bewijs en reliqua hadden te doen. Verplichte comparities waren er vier in 't jaar, n.l. op den derden Zaterdag in Januari, April, Juni en October; overigens stond het directeurs vrij om de brouwers zooveel malen bijeen te doen komen als zij dat noodig achtten. Afgezien van enkele latere wijzigingen van ondergeschikt belang hebben wij hier de organisatie zooals wij die ook uit het Resolutieboek der Gemeene Brouwers leeren kennen. Dan echter vormen de brouwers een confrerie, en elk spoor van gildedwang blijkt verdwenen. En voor de geschiedenis dier confrerie, en 't optreden der Delftsche brouwers in de nadagen van hun bedrijf, waarvoor ons veel meer en uitvoeriger gegevens ten dienste staan dan voor de vroegere tijden, kan ik naar mijn opstel „Uit de nadagen der Delftsche brouwnering" in de Economist van 1916 verwijzen.

DR. E. M. A. TIMMER. 